\title{
A Method of Evaluating Apple Juice Adulteration with Sucrose Based on Its Electrical Properties and RCC Model
}

\author{
Joanna Katarzyna Banach * (1) and Ryszard Żywica \\ Institute of Management and Quality, Faculty of Economics, University of Warmia and Mazury in Olsztyn, \\ 10-719 Olsztyn, Poland; ryszard.zywica@uwm.edu.pl \\ * Correspondence: katarzyna.banach@uwm.edu.pl
}

Citation: Banach, J.K.; Żywica, R. A Method of Evaluating Apple Juice Adulteration with Sucrose Based on Its Electrical Properties and RCC Model. Sustainability 2021, 13, 6716 . https://doi.org/10.3390/ su13126716

Academic Editor:

Katarzyna Włodarska

Received: 13 May 2021

Accepted: 11 June 2021

Published: 13 June 2021

Publisher's Note: MDPI stays neutral with regard to jurisdictional claims in published maps and institutional affiliations.

Copyright: (C) 2021 by the authors. Licensee MDPI, Basel, Switzerland. This article is an open access article distributed under the terms and conditions of the Creative Commons Attribution (CC BY) license (https:/ / creativecommons.org/licenses/by/ $4.0 /)$.

\begin{abstract}
This study aimed to identify possibilities of controlling basic quality attributes (total soluble solids, organic acids, density, $\mathrm{pH}$ ) and assessing the adulteration of natural dissociating solids with sucrose in apple juice produced from Malus domestica Borkh, var. Cortland, Idared, and Lobo (family Rosaceae Juss), using electrical parameters (conductivity $\mathrm{Z}, \mathrm{Y}$; capacity $\mathrm{C}_{\mathrm{p}}, \mathrm{C}_{\mathrm{s}}$ ) and the RCC equivalent electrical model. The feasibility of employing electrical parameters was established based on correlations between selected quality attributes of apple juices varying in sucrose contents in the extract $\mathrm{TSS}_{\mathrm{Conc}}(0 \%, 15 \%, 20 \%, 25 \%, 30 \%)$ and their electrical parameters measured in a frequency range of $100 \mathrm{~Hz}$ to $100 \mathrm{kHz}$. The significant $(p \leq 0.01)$ correlations obtained between the selected physicochemical parameters of juice $\left(\mathrm{TSS}_{\mathrm{Conc}}, \mathrm{OA}\right.$ ) and electrical properties point to the feasibility of using them as an alternative quality assessment method to the reference methods (refractometric or potentiometric titration) used by the external supervising bodies. The electrical parameters (including $\mathrm{Z}_{100 \mathrm{~Hz}}$ and $\mathrm{Y}_{100 \mathrm{~Hz}}$ ) measured in the RCC model can, in the future, aid the design of a simple tool for the quantitative determination of apple juice adulteration with sucrose. They also encourage further research of this electrical method as an alternative to traditional analytical methods for evaluating the authenticity or adulteration of commercial fruit juices with sucrose or other sweetening agents.
\end{abstract}

Keywords: apple juice; sucrose; adulteration; quality evaluation; electrical parameters; RCC equivalent electrical model; non-destructive method

\section{Introduction}

The growing demand for apple juice, observed on the market, is a strong economic driver for fraudulent food producers and processors who seek fast profits by concealing the inadequate quality, production method, and chemical composition of the product. One such adulteration method involves diluting natural apple juice with water or other cheaper juices and adding sweetening agents (sucrose, saccharin, aspartame) or acidifying agents (ascorbic acid or malic acid) [1-6]. According to the data given by Dasenaki and Thomaidis [7] based on the European Committee information, fruit juices are included in the top 10 food products with the highest risk of food fraud. In Poland, the market control authorities showed in 2019 that $7.4 \%$ of samples of juices and nectars were defective in terms of their physical parameters (a lowered glucose/fructose proportion in apple juice, an inflated TSS content in apple nectar), and 30.5\% of samples had faulty labeling.

To limit the use of such practices by producers, external (state) food control bodies are obliged to supervise the safety of consumers and the commercial quality of food offered on the domestic and EU markets and imported from external countries. Quality control of products available on the market is of particular importance when the act of adulteration can be verified via laboratory testing. The currently used measuring equipment can detect even trace amounts of ingredients, but the methods of food adulteration are also being improved by producers.

Analytical reference methods (recognized by Codex Alimentarius: refractometry, titrimetry, gravimetry, and potentiometry) and laboratory techniques (e.g., gas and liquid 
chromatography, mass spectroscopy, nuclear magnetic resonance, and ELISA tests) used to monitor food quality and safety are usually time-consuming, cost-intensive, harmful to the natural environment, and require collecting multiple samples. The advanced modern methods of evaluating juice authenticity are sensitive but can be applied only in large analytical laboratories because of their requirement for skilled and experienced staff [8-12]. Therefore, it is justified to search for methods that enable the rapid assessment and control of juice quality but also allow for real-time corrective actions (on/offline). These methods are expected to guarantee the detection of improper substances in a given juice and assure its authenticity [7,13-15].

Given their high reliability, sensitivity, short response time, and relatively low cost, the analyses of food products' electrical properties will aid the development of a simple, alternative tool for controlling quality through external, state bodies. Raw materials and food products constitute multi-component and multi-phase dispersion systems due to the content of water and compounds dissolved in them, such as mineral salts, acids, sugars, and also proteins and fats. The electrical properties of these products are determined by the concentration, size, and motility of positive and negative ions generated by the dissociation of molecules in the electrolyte and by temperature applied during heating. The methods for testing electrical properties, developed based on such electrical parameters as impedance, conductivity, capacitance, and dielectric constant, have gained in significance in recent years. They are employed to assess changes in the degree of fruit ripeness, damage, and spoilage [16-18]; determine contents of sugar, water, TSS, minerals, dry matter, and $\mathrm{pH}$ value; and to detect bacteria and impurities harmful to human health in fruits and fruit juices [6,15,19-24], among other applications. According to Muñoz-Huerta et al. [25], a reliable alternative to the conventional non-destructive techniques can be offered by electrical methods, including electrochemical impedance spectroscopy (EIS), which can provide information about the properties (structure, chemical composition) and behavior of the tested sample in the electric field [26,27]. However, the strength and degree of correlations between quality factors and electrical parameters are determined by the equivalent (substitute) electrical model of the product and by the voltage frequency applied [28]. Juansah and Yulianti [29] found that ion behavior in solvents (i.e., ionion and ion-solvent interactions) is also important. Widodo et al. [6], who investigated the effect of cane sugar and saccharin addition to apple cider manalagi on changes in its electrical parameters, showed that, at a frequency of up to $10 \mathrm{kHz}$, the type of the added sugar could be determined based on the impedance value. In turn, by measuring impedance and checking the degree of fit of the electric models described in the available literature [30-32], Ibba et al. [24] pointed to the usability of impedance and an original electric RRC model for the determination of changes occurring during apple and banana ripening. Our previous investigations showed the usability of the electrical properties in the system of the equivalent electrical model of food products (RCC) for determination of the properties and dilution degree of apple purée [33] and the contents of total soluble solids [34], mineral substances, ash, and dry matter in reconstituted apple juices [35]. Another study carried out by our research group in this research area was the basis for patenting the electrical method for predicting TSS $_{\text {Conc }}$ content in apple juice [36].

With the above in mind, the innovative studies were continued to determine the feasibility of evaluating the adulteration of natural and solid substances dissociating (TSS Conc $_{\text {) }}$ in apple juice with sucrose and selected conductivity and capacity parameters. The usability of the measuring system in this study was determined based on mathematical relationships (the strength of correlation) between selected quality features of apple juices differentiated by the percentage content of sucrose in the extract and their electrical parameters.

\section{Materials and Methods}

The research material included water solutions of apple juice concentrate (further referred to as "apple juices"), with total soluble solids (TSS) content of $10.5^{\circ} \mathrm{Bx}$ and total acidity not lower than $4.5 \mathrm{~g} \cdot \mathrm{L}^{-1}$, prepared from industrially produced concentrates 
(Tymbark S.A. in Olsztynek, Poland). The juice was produced from apples (species Malus domestica Borkh, family Rosaceae Juss; var. Cortland, Idared, and Lobo) grown in Poland (Grójec region, known as the biggest orchard in Europe). The concentrate of apple juice, acquired over 31 consecutive processing days $(n=31)$, was characterized by an average TSS $=66.3^{\circ} \mathrm{Bx}$, an organic acid content of $3.11 \mathrm{~g} \cdot 100 \mathrm{~g}^{-1}$, active acidity $(\mathrm{pH})$ of 3.17 , and a density of $1.3379 \mathrm{~g} \cdot \mathrm{cm}^{-3}$. The TSS content differed insignificantly in all 31 examined samples of the concentrate $(\mathrm{CV}=1.77 \%)$. These differences resulted from differentiation of the raw material used for manufacturing and were mainly related to apple variety and fruit maturity [37]. Water used to prepare apple juices from concentrates $(n=31)$ originated from the water mains and met the drinking water requirements [38]. The water solutions of apple juice concentrate (apple juices) intended for analyses were standardized

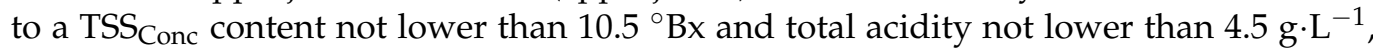
which corresponds to the characteristics (approximate chemical composition) of apple juice offered in the Polish market. The analytical material included five types of apple juices with sucrose addition (SD) and with a TSS content of $10.5^{\circ} \mathrm{Bx}$. The samples were prepared by the partial replacement of reconstituted apple juice, derived from apple juice concentrate (TSS $_{\text {Conc }}$ ) with sucrose (white sugar from Súdzucker Polska S.A, purchased on the market), the content of which in the extract reached $0 \%, 15 \%, 20 \%, 25 \%$, and $30 \%$. Sucrose was integrated into the juice using a magnetic stirrer MS200 (AMTAST, Poland).

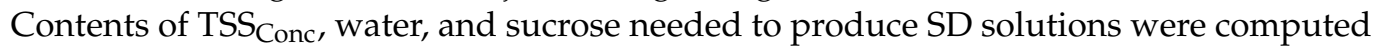
from the balance of extract components and density. Each time, the computations were performed for seven series of samples. Water density was assumed at $d_{20}=1 \mathrm{~g} \cdot \mathrm{cm}^{-3}$. The solutions to be analyzed (SD) were stored in glass bottles (volume $0.75 \mathrm{~L}$, juice content $0.75 \mathrm{~L}$, headspace filled with air). The filled bottles were placed in an ICP 500 type incubator chamber (Memmert, Germany) at a temperature of $20 \pm 0.1{ }^{\circ} \mathrm{C}$ for $24 \mathrm{~h}$, and after that period all the analyses were performed.

The feasibility of using the proposed electrical method for evaluating the apple juice authenticity and determining its adulteration with sucrose was identified employing traditional analytical methods recommended by the International Federation of Fruit Juice Producers [39].

\subsection{Physicochemical Parameters}

Physicochemical analyses of samples (concentrate of apple juice and apple juice) conducted at $20^{\circ} \mathrm{C}$ included the following determinations:

- Total acidity—by titration method [40];

- Total soluble solids content (TSS) — by refractometric method [41];

- Organic acids content-by titration method [40]

- Density - by pycnometric method [42];

- Active acidity - by pH measurements using a Piccolo PLUS, ATC pH meter (Hanna Instruments, USA) [43].

\subsection{Electrical Measurements}

The measurements of the electrical parameters of apple juice with sucrose addition were carried out using a measuring system (Figure 1), comprising:

- A glass container $(\mathrm{L} \times \mathrm{In} \times \mathrm{H}: 94 \times 55 \times 80 \mathrm{~mm})$ equipped with two plate electrodes made of stainless steel, mounted on the two opposite smaller walls of the container;

- A stainless-steel container equipped with a water jacket that was coupled to a thermostat (PolyScience, USA);

- $\quad$ An HP 4263B LCR meter (Hewlett Packard, USA). 


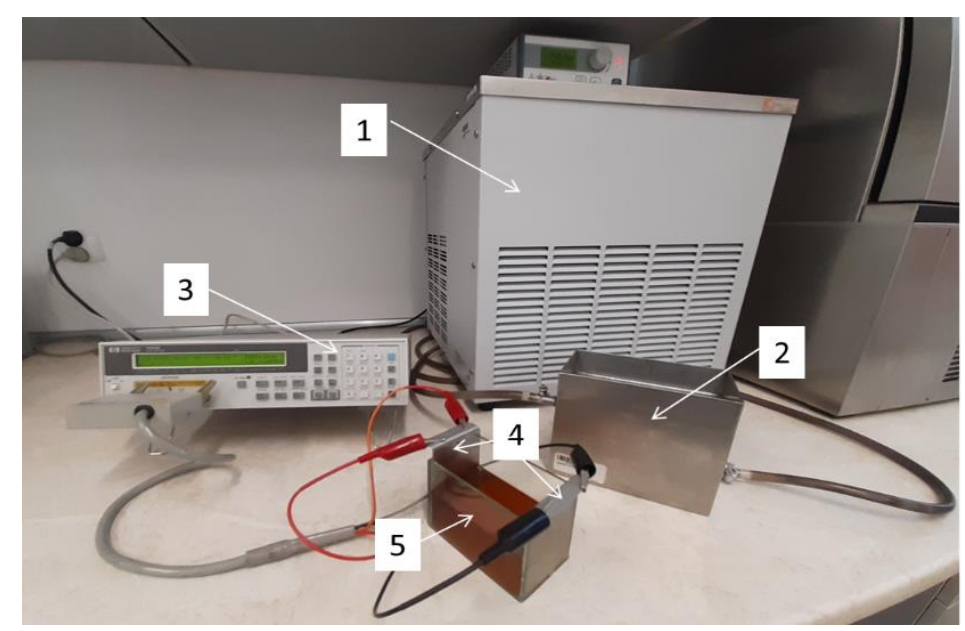

Figure 1. A set of devices of the measurement system used for electrical conductivity examination of the apple juice concentrate: 1-thermostat, 2-water jacket; 3-LCR device, type HP 4263B, 4 -measuring glass cell with plate electrodes, 5-examined juice.

The prepared samples of apple juice with $0 \%$ to $30 \%$ addition of sucrose were weighed and poured into ca. $200-\mathrm{cm}^{3}$ glass containers, which were placed in a steel container with a water jacket coupled to a thermostat with a temperature set at $20 \pm 0.05^{\circ} \mathrm{C}$. The electrical measurements of apple juice were performed starting with the sample having the lowest $(0 \%)$ and ending with the sample having the highest (30\%) sucrose content in the extract. The last measurement was conducted for the apple juice concentrate used to prepare a given series of dilutions. Prior to the measurements, the LCR meter with the wires supplied was calibrated. Next, the wires were coupled to the LCR meter, and measurements were carried out for impedance $(\mathrm{Z})$, admittance $(\mathrm{Y})$, equivalent parallel capacitance $\left(\mathrm{C}_{\mathrm{p}}\right)$, and equivalent serial capacitance $\left(C_{s}\right)$ at the voltage of $200 \mathrm{mV}$ and frequencies of $100 \mathrm{~Hz}, 1 \mathrm{kHz}$, and $100 \mathrm{kHz}$, in 3 replicates for each sample. The results of juice impedance and admittance measurements are presented only for $\mathrm{f}=100 \mathrm{~Hz}$ because of no significant differences between $100 \mathrm{~Hz}$ and $100 \mathrm{kHz}$ frequencies. The analysis of the electrical properties of water solutions of the apple juice concentrate was conducted according to an RCC equivalent model (serial-parallel resistance + capacitance), as shown in Figure 2, elaborated by our research group [34,44].

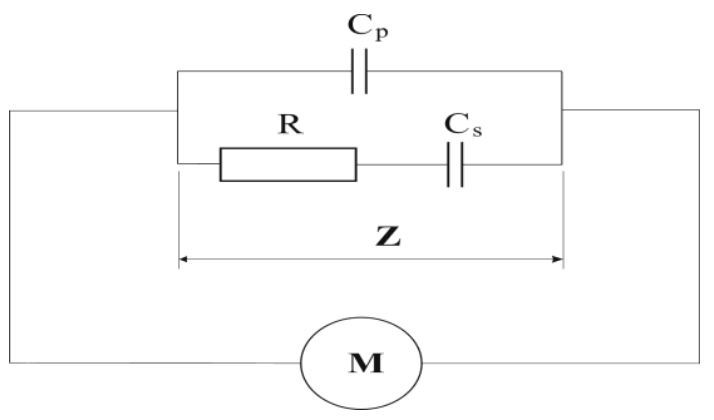

Figure 2. RCC equivalent model for measuring of electrical properties of apple juice (Z-impedance; $\mathrm{R}$-resistance; $\mathrm{C}_{\mathrm{s}}$ - series equivalent capacitance; $\mathrm{C}_{\mathrm{p}}$ - parallel equivalent capacitance; $\mathrm{M}$-measuring device).

\subsection{Statistical Analysis}

The statistical analysis of data was performed using Statistica 13.1 (StatSoft Inc.) software. The results of analyses are presented as means \pm standard deviation. Analysis of variance and Duncan's multiple comparisons test were conducted at significance levels of $p \leq 0.05$ and $p \leq 0.01$. 
Correlation and linear regression equations $(\mathrm{y}=\mathrm{a} \pm \mathrm{bx})$ were calculated to determine the correlations between selected physicochemical distinguishing features of quality, including total soluble solids from the concentrate $\left(\right.$ TSS $\left._{C o n c}\right)$ and organic acids $(\mathrm{OA})$, and their conductivity $(\mathrm{Z}, \mathrm{Y})$ and capacity $\left(\mathrm{C}_{\mathrm{p}}, \mathrm{C}_{\mathrm{s}}\right)$, electrical parameters measured at frequencies of $100 \mathrm{~Hz}, 1 \mathrm{kHz}$, and $100 \mathrm{kHz}$. The results of statistical analyses are presented as correlation coefficients (r), and the level of significance was calculated $(p)$.

\section{Results and Discussion}

\subsection{Changes in the Physicochemical and Conductivity Parameters}

The physicochemical characteristics of apple juice demonstrated that the sucrose content increase in TSS from $0 \%$ to $30 \%$ significantly $(p \leq 0.01)$ reduced the content of organic acids (OA) dissociating in juice and capable of transferring electrical charges and increased the content of soluble but not dissociating sucrose, thereby deteriorating the electrical conductivity of this juice. These observations point to the feasibility of assessing apple juice based on the content of organic acids (OA), represented mainly by malic acid as its quality indicator [45]. In contrast, no significant differences were noted between TSS content, $\mathrm{pH}$, and density (Table 1). The lack of these differences indicates that the reference (analytical, for instance TSS, $\mathrm{pH}$, or density) methods used today fail to detect juice adulteration with both the lowest and the highest sucrose addition level [12]. In this context, it is justified to continue research on juice adulteration using modern instrumental methods, including the electrical methods that are inexpensive, rapid, and simple to perform and effective in terms of sensitivity, repeatability, and non-invasiveness.

Table 1. Value changes (mean values \pm standard deviation) of measured physicochemical and electrical parameters of aqueous apple juice concentrate solutions, depending on sucrose content in extract $(\mathrm{n}=21)$.

\begin{tabular}{|c|c|c|c|c|c|c|}
\hline \multirow{2}{*}{$\begin{array}{l}\text { Sucrose Content } \\
\text { in the Extract }(\%)\end{array}$} & \multicolumn{4}{|c|}{ Physicochemical Parameters } & \multicolumn{2}{|c|}{ Electrical Parameters, $f=100 \mathrm{~Hz}$} \\
\hline & TSS $\left({ }^{\circ} \mathbf{B x}\right)$ & $\mathrm{pH}$ & OA $\left(g \cdot 100 g^{-1}\right)$ & $\mathrm{D}\left(\mathrm{g} \cdot \mathrm{cm}^{-3}\right)$ & $Z(\Omega)$ & $\mathrm{Y}(\mathrm{mS})$ \\
\hline 0 & $10.56 \pm 0.16^{\mathrm{a}}$ & $3.36 \pm 0.09^{a}$ & $0.48 \pm 0.02^{a}$ & $1.0441 \pm 0.0007^{\mathrm{a}}$ & $187.14 \pm 0.98^{a}$ & $5.345 \pm 0.027^{\mathrm{a}}$ \\
\hline 15 & $10.56 \pm 0.11^{\mathrm{a}}$ & $3.36 \pm 0.08^{a}$ & $0.40 \pm 0.01^{b}$ & $1.0438 \pm 0.0006^{\mathrm{a}}$ & $210.79 \pm 1.54^{b}$ & $4.745 \pm 0.034^{b}$ \\
\hline 20 & $10.51 \pm 0.11^{\mathrm{a}}$ & $3.35 \pm 0.08^{a}$ & $0.37 \pm 0.01^{c}$ & $1.0439 \pm 0.0009^{a}$ & $220.73 \pm 2.24^{c}$ & $4.532 \pm 0.046^{c}$ \\
\hline 25 & $10.51 \pm 0.09^{a}$ & $3.35 \pm 0.08^{\mathrm{a}}$ & $0.35 \pm 0.01^{\mathrm{d}}$ & $1.0436 \pm 0.0007^{\mathrm{a}}$ & $232.56 \pm 1.79 \mathrm{~d}$ & $4.301 \pm 0.033^{\mathrm{d}}$ \\
\hline 30 & $10.51 \pm 0.12^{\mathrm{a}}$ & $3.35 \pm 0.08^{\mathrm{a}}$ & $0.32 \pm 0.01^{\mathrm{e}}$ & $1.0435 \pm 0.0007^{\mathrm{a}}$ & $244.78 \pm 1.90^{\mathrm{e}}$ & $4.086 \pm 0.031^{\mathrm{e}}$ \\
\hline
\end{tabular}

TSS—-total soluble solids; OA—organic acids; D—density; Z-impedance; Y-admittance; ${ }^{\text {a-e }}$-mean values in columns indicated with various letters are significantly different at $p \leq 0.01$;

The measurements of conductivity parameters-impedance and admittance-were performed assuming that the conductivity properties are an approximate measure of the relative number, type, and concentration of free electric charges present in juice and that the electric field generated between two electrodes can be used to determine their ability to conduct electric current in an electrolyte solution [22,24,46].

Results of these measurements demonstrated that the conductivity properties of the analyzed apple juice changed in response to its modified chemical composition. An increase in sucrose content of the extract from $0 \%$ to $30 \%$ and a decrease in OA content from 0.48 to $0.32 \mathrm{~g} \cdot 100 \mathrm{~g}^{-1}$ in the analyzed solutions caused the impedance $(Z)$ values measured at the current frequency of $\mathrm{f}=100 \mathrm{~Hz}\left(\mathrm{Z}_{100 \mathrm{~Hz}}\right)$ to increase from ca. 187 to ca. $245 \Omega$. In turn, the values of admittance $\left(\mathrm{Y}_{100 \mathrm{~Hz}}\right)$ decreased from ca. 5.3 to ca. $4.1 \mathrm{mS}$. Significant $(p \leq 0.01)$ differences were also noted between $Z_{100 \mathrm{~Hz}}$ and $\mathrm{Y}_{100 \mathrm{~Hz}}$ values of apple juices differing in sucrose content in TSS (Table 1). This means that the solutions' capability to conduct electric current diminished along with the increased contents of electrically neutral sucrose in TSS. Presumably, this decrease is due to a decreased number of ions able to transfer electrical charges and their motility being reduced proportionally to the increasing concentration of sucrose (being a dielectric) and to a decreasing concentration of the electrolyte [29,47]. This theory might be confirmed by significant changes observed in the concentrations of $\mathrm{OA}$ 
in the solutions tested, being dissociated carriers of electrical charges in apple juices. This is due to the fact that the mineral components of apple juice are mainly represented by small ions, i.e., potassium $\left(1.12 \mathrm{~g} \cdot \mathrm{L}^{-1}\right)$, calcium $\left(0.07 \mathrm{~g} \cdot \mathrm{L}^{-1}\right)$, phosphorus $\left(0.06 \mathrm{~g} \cdot \mathrm{L}^{-1}\right)$, and magnesium $\left(0.04 \mathrm{~g} \cdot \mathrm{L}^{-1}\right)$ [48], which are the main determinants of its electrical conductivity.

The results obtained became the basis for determining equations of linear regression between selected quality attributes of apple juice and its electrical parameters $(\mathrm{Z}, \mathrm{Y})$ as a function of sucrose content in TSS. The correlations obtained, determined by y $=\mathrm{a} \pm \mathrm{bx}$ type equations at a significance level of $p \leq 0.01$ and a correlation coefficient of $r \geq 0.99$, can be used to determine the content of the extract originating from the concentrate (TSS $_{\text {Conc }}$ ) in the total TSS content in apple juices based on measurements of $Z_{100 \mathrm{~Hz}}$ and $\mathrm{Y}_{100 \mathrm{~Hz}}$ conducted at $\mathrm{f}=100 \mathrm{~Hz}$. To check these correlations, the usefulness of the determined regression equations was verified by substituting $Z_{100 \mathrm{~Hz}}$ and $Y_{100 \mathrm{~Hz}}$ for the variable " $x$ " (Table 1).

The TSS $_{\text {Conc }}$ contents computed based on regression equations in the juices with the assumed $100 \%$ and $70 \%$ TSS $_{\text {Conc, }}$, i.e., with $0 \%$ and $30 \%$ sucrose content in TSS, were similar to these assumed values, i.e., $98.57 \%$ and $68.78 \%$ TSS $_{\text {Conc }}$ (based on $\mathrm{Z}_{100 \mathrm{~Hz}}$ ) as well as $99.90 \%$ and $69.79 \%$ TSS $_{\text {Conc }}$ (based on $\mathrm{Y}_{100 \mathrm{~Hz}}$ ), respectively. The analysis of correlations between OA content and values of $Z_{100 \mathrm{~Hz}}$ and $Y_{100 \mathrm{~Hz}}$ (Table 2) showed that these electrical parameters allow for very precise $(r=-0.962 ; r=0.972, p \leq 0.01)$ determination of OA

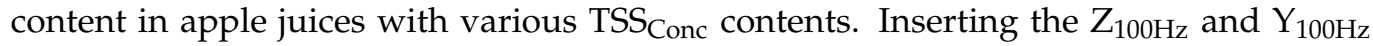
values typical of apple juices with sucrose contents of $0 \%$ and $30 \%$ in TSS to the regression equations produced $\mathrm{OA}$ concentrations similar to (for $\mathrm{Z}_{100 \mathrm{~Hz}}, \mathrm{OA}=0.47$ and $\mathrm{OA}=0.31$ ) or the same (for $\mathrm{Y}_{100 \mathrm{~Hz}}$ ) as the values assumed in the solutions tested $\left(0.48\right.$ and $\left.0.32 \mathrm{~g} \cdot 100 \mathrm{~g}^{-1}\right)$. This means that the above equations enable highly precise determination of TSS Conc $_{\text {and }}$ OA contents in apple juice (Table 2).

Table 2. Linear regression analysis of total soluble solids from concentrate $\left(\mathrm{TSS}_{\mathrm{Conc}}\right)$ and organic acids (OA) content of aqueous apple juice concentrate solutions as a function of average impedance and admittance values $\left(\mathrm{Z}_{100 \mathrm{~Hz}}, \mathrm{Y}_{100 \mathrm{~Hz}}\right.$; Table 1), with sucrose addition from $0 \%$ to $30 \%$.

\begin{tabular}{|c|c|c|c|c|c|c|}
\hline Regression Equation & $\mathbf{r}$ & $p$ & Calcu & Values & \multicolumn{2}{|c|}{ Established/Measured Values } \\
\hline $\mathrm{TSS}_{\text {Conc }}(\%)=195.267-0.517^{*} \mathrm{Z}_{100 \mathrm{~Hz}}$ & -0.990 & $\leq 0.01$ & 98.57 & 68.78 & \multirow{2}{*}{100} & \multirow{2}{*}{70} \\
\hline $\operatorname{TSS}_{\text {Conc }}(\%)=-26.926+23.669 * Y_{100 \mathrm{~Hz}}$ & 0.997 & $\leq 0.01$ & 99.90 & 69.79 & & \\
\hline $\mathrm{OA}\left(\mathrm{g} \cdot 100 \mathrm{~g}^{-1}\right)=0.998-0.003^{*} \mathrm{Z}_{100 \mathrm{~Hz}}$ & -0.962 & $\leq 0.01$ & 0.47 & 0.31 & \multirow{2}{*}{0.48} & \multirow{2}{*}{0.32} \\
\hline $\mathrm{OA}\left(\mathrm{g} \cdot 100 \mathrm{~g}^{-1}\right)=(-0.205)+0.129^{*} \mathrm{Y}_{100 \mathrm{~Hz}}$ & 0.972 & $\leq 0.01$ & 0.48 & 0.32 & & \\
\hline
\end{tabular}

$\mathrm{r}$-correlation coefficient; $p$-level of significance; $\mathrm{Z}_{100 \mathrm{~Hz}}$-impedance measured at $\mathrm{f}=100 \mathrm{~Hz} ; \mathrm{Y}_{100 \mathrm{~Hz}}$-admittance measured at $\mathrm{f}=100 \mathrm{~Hz}$.

\subsection{Changes in Capacitance Properties}

The results of the measurements of equivalent parallel capacitance $\left(C_{p}\right)$ demonstrated that increasing sucrose content in TSS of apple juice caused the $C_{p}$ values to decrease at all measuring voltage frequencies tested. The statistical analysis showed that the $C_{p}$ values of the solutions without sucrose addition $(0 \%$ ) and the solutions with $15 \%, 20 \%, 25 \%$, and $30 \%$ sucrose content in TSS differed significantly when measured at $\mathrm{f}=100 \mathrm{~Hz}$ and $\mathrm{f}=1 \mathrm{kHz}$ and did not differ significantly at $\mathrm{f}=100 \mathrm{kHz}$ (Table 3).

Likewise, the $C_{p}$ values of the equivalent serial capacitance $\left(C_{s}\right)$ also depended on both the measuring voltage frequency and sucrose addition. At $\mathrm{f}=100 \mathrm{~Hz}$, increasing the content of sucrose $(0-30 \%)$ and consequently decreasing the content of TSS of the concentrate $\left(\mathrm{TSS}_{\text {Conc }}\right.$ ) caused the $\mathrm{C}_{\mathrm{s}}$ values to increase. At $\mathrm{f}=1 \mathrm{kHz}$, the $\mathrm{C}_{\mathrm{s}}$ values increased insignificantly, whereas at $\mathrm{f}=100 \mathrm{kHz}$ they decreased along with increasing sucrose content in TSS (Table 3). 
Table 3. Value changes (mean values \pm standard deviation) electrical capacitance $\left(C_{p}, C_{s}\right)$ of aqueous apple juice concentrate solutions, depending on sucrose content in total soluble solids $(\mathrm{n}=21)$.

\begin{tabular}{|c|c|c|c|c|c|c|}
\hline \multirow{2}{*}{$\begin{array}{l}\text { Sucrose Content } \\
\text { in the Extract (\%) }\end{array}$} & \multicolumn{3}{|c|}{$C_{p}(n F)$} & \multicolumn{3}{|c|}{$C_{s}(\mu F)$} \\
\hline & $100 \mathrm{~Hz}$ & $1 \mathrm{kHz}$ & $100 \mathrm{kHz}$ & $100 \mathrm{~Hz}$ & $1 \mathrm{kHz}$ & $100 \mathrm{kHz}$ \\
\hline 0 & $298.38 \pm 6.91 \mathrm{aA}$ & $5.128 \pm 0.123^{a B}$ & $0.022 \pm 0.001 \mathrm{aC}$ & $243.48 \pm 5.60^{\mathrm{aA}}$ & $146.20 \pm 3.36^{\mathrm{aB}}$ & $3.485 \pm 0.189^{\mathrm{aC}}$ \\
\hline 15 & $232.09 \pm 5.40^{\mathrm{bA}}$ & $4.035 \pm 0.096^{\mathrm{bB}}$ & $0.021 \pm 0.001 \mathrm{aC}$ & $246.67 \pm 5.68^{\mathrm{aA}}$ & $144.50 \pm 2.95^{\mathrm{aB}}$ & $2.851 \pm 0.132^{b C}$ \\
\hline 20 & $206.86 \pm 4.54^{\mathrm{cA}}$ & $3.632 \pm 0.089^{\mathrm{cB}}$ & $0.021 \pm 0.001 \mathrm{abC}$ & $252.22 \pm 6.14 \mathrm{abA}$ & $146.31 \pm 2.82 \mathrm{aB}$ & $2.625 \pm 0.144^{c C}$ \\
\hline 25 & $184.43 \pm 4.53 \mathrm{dA}$ & $3.253 \pm 0.064 \mathrm{~dB}$ & $0.020 \pm 0.001 \mathrm{aacC}$ & $254.97 \pm 6.04^{\mathrm{acd} A}$ & $146.99 \pm 2.74^{\mathrm{aB}}$ & $2.421 \pm 0.107 \mathrm{dC}$ \\
\hline 30 & $165.81 \pm 3.94 \mathrm{eA}$ & $2.934 \pm 0.050 \mathrm{eB}$ & $0.020 \pm 0.001$ aadeC & $255.72 \pm 6.91$ aaefA & $146.81 \pm 2.70 \mathrm{aB}$ & $2.216 \pm 0.075^{\mathrm{eC}}$ \\
\hline
\end{tabular}

${ }^{\mathrm{a}-\mathrm{e}}-$ mean values in columns indicated with various small letters are significantly different at $p \leq 0.05$; ${ }^{\mathrm{A}-\mathrm{C}}-$ mean values in rows indicated with various capital letters are significantly different at $p \leq 0.05$.

The statistical analysis of changes in $C_{p}$ and $C_{s}$ values of the sweetened apple juices demonstrated that not all of them differed significantly between each other. At $\mathrm{f}=100 \mathrm{~Hz}$, the $C_{s}$ value of the juice without sucrose addition $(0 \%)$ differed significantly $(p \leq 0.05)$ from the $\mathrm{C}_{\mathrm{s}}$ values of the juices with $20 \%, 25 \%$, and $30 \%$ sucrose content in TSS, whereas the $\mathrm{C}_{\mathrm{s}}$ value of the juices with $30 \%$ and $25 \%$ sucrose content differed from the corresponding values measured for the juices with $0 \%$ and $15 \%$ sucrose content in TSS. In contrast, the differences between the $\mathrm{C}_{\mathrm{S}}$ values measured at $\mathrm{f}=1 \mathrm{kHz}$ for the juices without sucrose and with sucrose addition $(20 \%, 25 \%$, and $30 \%)$ did not differ significantly. The statistical analysis of results of $C_{s}$ measurements conducted at $f=100 \mathrm{kHz}$ for the juices differing in sucrose addition showed significant differences between values $(p \leq 0.05)$. This means that the increase in sucrose content of TSS was accompanied by the deteriorating ability of the water solutions of apple juice concentrate (apple juice) to accumulate electric charges (Table 3).

As in the case of $Z_{100 \mathrm{~Hz}}$ and $Y_{100 \mathrm{~Hz}}$ values, the linear regression analysis carried out for changes in $C_{p}$ and $C_{s}$ values in the function of varying sucrose contents in TSS demonstrated that these parameters also enable the highly probable $(p \leq 0.01)$ determination

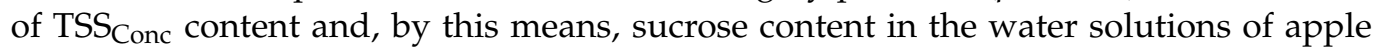
juice concentrate, but only at the selected frequencies of the measuring voltage. For $C_{p}$, significant $(\mathrm{p} \leq 0.01)$ correlations were obtained at $\mathrm{f}=100 \mathrm{~Hz}$ and $\mathrm{f}=1 \mathrm{kHz}(\mathrm{r}=0.994)$, whereas for $C_{s}$ it was only at $f=100 \mathrm{kHz}(r=0.962)$. Verifying the correctness and accuracy of the TSS ${ }_{\text {Conc }}$ and OA regression equations determined based on $C_{p}$ and $C_{s}$ measurements (Table 4), it was observed that the same values as the assumed values were achieved only for OA content. The computations performed for TSS showed that similar values were obtained in the juices with $100 \%$ and $70 \%$ TSS $_{\mathrm{Conc}}$. For $\mathrm{C}_{\mathrm{p} 100 \mathrm{~Hz}}$ and $\mathrm{C}_{\mathrm{p} 1 \mathrm{kHz}}$, the $\mathrm{TSS}_{\mathrm{Conc}}$ content was $99.85 \%$ and $70.59 \%$ as well as $99.80 \%$ and $70.47 \%$, respectively. In turn, for $\mathrm{C}_{\mathrm{s} 100 \mathrm{kHz}}$, the value was $98.67 \%$ and $71.03 \%$, respectively (Table 4 ). This means that, as in the case of the conductivity parameters, the above equations enable highly probable determination of TSS $_{\text {Conc }}$ and OA contents in apple juices using the capacitance parameters.

The significant differences in the values of the conductivity $(\mathrm{Z}, \mathrm{Y})$ and capacitance parameters $\left(C_{p}, C_{s}\right)$ in the function of sucrose content in TSS as well as the regression equations obtained based on these values affirm the usability of the RCC model for determining sucrose content in apple juice. In turn, considering that the $\mathrm{Z}$ and $\mathrm{Y}$ measurements are more rapid and simpler to conduct than the determination of organic acids content (OA) with the reference method, it was found advisable to continue the research on other types of fruit juices. As for the measuring cell, the system with two parallel flat electrodes can be adapted for determining sucrose content in juices, similarly to the investigations performed by Widodo et al. [46]. The results obtained in our experiment can be used in the future to develop a screening technique for state bodies that would allow them to evaluate the authenticity of commercial juices or their adulteration with sucrose. In turn, the significant correlations demonstrated between the conductivity parameters of apple juice at $\mathrm{f}=100 \mathrm{~Hz}$ 
(i.e., twice the electric grid frequency of $50 \mathrm{~Hz}$ ) will enable the design of portable devices as an alternative to standardized methods in terms of price and simplicity.

Table 4. Linear regression analysis of total soluble solids from concentrate $\left(\mathrm{TSS}_{\mathrm{Conc}}\right)$ and organic acids (OA) content of aqueous apple juice concentrate solutions as a function of electrical capacitance $\left(C_{p}, C_{s}\right)$ with sucrose addition from $0 \%$ to $30 \%$.

\begin{tabular}{|c|c|c|c|c|c|c|}
\hline \multirow{2}{*}{$\begin{array}{c}\text { Regression Equation } \\
\text { TSS }_{\text {Conc }}(\%)=33.981+0.221^{*} \mathrm{C}_{\mathrm{p} 100 \mathrm{~Hz}}\end{array}$} & \multirow{2}{*}{$\frac{\mathbf{r}}{0.994}$} & \multirow{2}{*}{$\begin{array}{c}p \\
\leq 0.01\end{array}$} & \multicolumn{2}{|c|}{ Calculated Values } & \multicolumn{2}{|c|}{ Established/Measured Values } \\
\hline & & & 99.85 & 70.59 & \multirow{3}{*}{100} & \multirow{3}{*}{70} \\
\hline $\operatorname{TSS}_{\text {Conc }}(\%)=31.252+13.368 * \mathrm{C}_{\mathrm{p} 1 \mathrm{kHz}}$ & 0.994 & $\leq 0.01$ & 99.80 & 70.47 & & \\
\hline $\mathrm{TSS}_{\mathrm{Con}}(\%)=22.805+21.766^{*} \mathrm{C}_{\mathrm{s} 100 \mathrm{kHz}}$ & 0.962 & $\leq 0.01$ & 98.67 & 71.03 & & \\
\hline $\mathrm{OA}\left(\mathrm{g} \cdot 100 \mathrm{~g}^{-1}\right)=0.1244+0.0012^{*} \mathrm{C}_{\mathrm{p} 100 \mathrm{~Hz}}$ & 0.975 & $\leq 0.01$ & 0.48 & 0.32 & \multirow{3}{*}{0.48} & \multirow{3}{*}{0.32} \\
\hline $\mathrm{OA}\left(\mathrm{g} \cdot 100 \mathrm{~g}^{-1}\right)=0.1084+0.0731^{*} \mathrm{C}_{\mathrm{p} 1 \mathrm{kHz}}$ & 0.977 & $\leq 0.01$ & 0.48 & 0.32 & & \\
\hline $\mathrm{OA}\left(\mathrm{g} \cdot 100 \mathrm{~g}^{-1}\right)=0.0543+0.1219^{*} \mathrm{C}_{\mathrm{s} 100 \mathrm{kHz}}$ & 0.969 & $\leq 0.01$ & 0.48 & 0.32 & & \\
\hline
\end{tabular}

$\mathrm{r}$-correlation coefficient; $\mathrm{p}$-level of significance; $\mathrm{Cp}_{100 \mathrm{~Hz}}$ - equivalent parallel capacitance, measured at $\mathrm{f}=100 \mathrm{~Hz} ; \mathrm{Cs}_{100 \mathrm{kHz}}$-equivalent serial capacitance, measured at $\mathrm{f}=100 \mathrm{kHz}$.

Ibba et al. [24] used impedance measurements with the electrochemical impedance spectroscopy (EIS) method to determine the ripening degree of apples and bananas by employing RC and RRC electrical models differing in the variants of coupling resistance $(\mathrm{R})$ with capacitance (C) in a frequency range from $100 \mathrm{~Hz}$ to $85 \mathrm{kHz}$. Based on the example of the RRC model, the authors demonstrated that Warburg's element $\left(\mathrm{Y}_{0}\right)$ added to the model of serial resistance $\left(R_{s}\right)$ connected to parallel resistance $\left(R_{p}\right)$ and capacitance $\left(C_{p}\right)$ provided the best fitting to the experimental data. The Warburg impedance element was intended for the explanation of the mass diffusion process occurring at the interface between an electrode and an electrolyte, specifically the diffusion of ions towards the electrode. This is due to the fact that the electrical properties of plant tissues are determined by both the features of cellular components and membrane structures. Therefore, the measurements of their electrical parameters are summarized at different frequency ranges, other than for liquids. The cell membranes of plant tissues probably influence the electric capacity of the system and make the RCC model more useful for the evaluation of the fruit ripeness compared to the RRC model. The RCC model was also applied by Mabrook and Petty [49,50] to determine the chemical composition and dilution of milk. Thus, this model can be deemed more versatile than the equivalent RRC model employed in the analysis of the physicochemical properties of food products, in which the equivalent parallel capacitance $\left(C_{p}\right)$ is replaced by the equivalent parallel resistance $\left(R_{p}\right)$. The feasibility of employing the RCC model to assess the quality of milk and juices is additionally justified by granted patents [36,51].

\section{Conclusions}

The significant $(p \leq 0.01)$ mathematical correlations obtained between the content of total soluble solids in apple juices prepared from the concentrate $\left(\mathrm{TSS}_{\text {Conc }}\right)$, the content of organic acids $(\mathrm{OA})$, and the values of electrical parameters $\left(\mathrm{Z}, \mathrm{Y}, \mathrm{C}_{\mathrm{p}}, \mathrm{C}_{\mathrm{s}}\right)$ measured in the system of the RCC equivalent electrical model, point to the feasibility of using them to evaluate the adulteration of natural dissociating solid components with sucrose.

The computations based on regression equations demonstrated a high usability of conductivity parameters $(\mathrm{Z}, \mathrm{Y})$ measured in a frequency range from $100 \mathrm{~Hz}$ to $100 \mathrm{kHz}$. The use of $Z_{100 \mathrm{~Hz}}$ and $Y_{100 \mathrm{~Hz}}$ is recommended for designing an alternative, inexpensive, and portable prototype of the device due to practical applications. In turn, the measurements of capacitance can be useful only at selected frequencies $\left(\mathrm{C}_{\mathrm{p}}: 100 \mathrm{~Hz}\right.$ and $\left.1 \mathrm{kHz} ; \mathrm{C}_{\mathrm{s}}: 100 \mathrm{kHz}\right)$.

The method developed and presented in this work is faster, more effective, and more objective than traditional analytical methods used to detect adulteration of fruit juices with sucrose. This method can be used to determine the dissociating components (capable of 
transferring electric charges), mainly organic acids, which are the basic quality determinants of apple juice and other fruit juices. Therefore, the results obtained provide a sound basis for further research on the improvement of this electric method as an alternative to traditional analytical methods used to detect adulteration of commercial fruit juices with sucrose and other sweeteners.

Author Contributions: Conceptualization, R.Ż., J.K.B. methodology, R.Ż; validation, R.Ż., J.K.B. formal analysis, J.K.B. and R.Ż..; investigation, R.Ż., J.K.B.; data curation, R.Ż.; writing-original draft preparation, R.Ż., J.K.B.; writing-review and editing, J.K.B.; funding acquisition, R.Ż., J.K.B. All authors have read and agreed to the published version of the manuscript.

Funding: This work was supported by the Ministry of Science and Higher Education of Poland as part of statutory activities from Faculty of Economics (No. 22.610.100-110) at the University of Warmia and Mazury in Olsztyn, Poland.

Institutional Review Board Statement: Not applicable.

Informed Consent Statement: Not applicable.

Data Availability Statement: Not applicable.

Conflicts of Interest: The authors declare no conflict of interest.

\section{References}

1. Thavarajah, P.; Low, N.H. Adulteration of apple with pear juice: Emphasis on major carbohydrates, proline, and arbutin. J. Agric. Food Chem. 2006, 54, 4861-4867. [CrossRef] [PubMed]

2. Magdas, D.A.; Cristea, G.; Puscas, R.; Tusa, F. The use of isotope ratios in commercial fruit juices authentication. Rom. J. Phys. 2014, 59, 355-359. [CrossRef]

3. Spinelli, F.R.; Dutra, S.V.; Carnieli, G.; Leonardelli, S.; Drehmer, A.P.; Vanderlinde, R. Detection of addition of apple juice in purple grape juice. Food Control. 2016, 69, 1-4. [CrossRef]

4. Prusova, P.; Kružik, V.; Seidl, J.; Čížková, H. Use of electrochemical impedance spectroscopy to verify orange juice authenticity. Chem. Listy 2017, 111, 258-263.

5. Bocharova, O.V.; Reshta, S.P.; Bocharova, M.Y.; Eshtokin, V.I. Determination of apple juice authenticity using gas chromatographymass spectrometry. volt-ampere and new conductometric methods. J. Sci. Food Agric. 2018, 98, 4692-4699. [CrossRef]

6. Widodo, C.S.; Sugianto, W.; Effendi, A.M.; Saroja, G. Study on the effect of sugar canes and saccharin to the value of electrical impedance of apple cider manalagi (Malus sylvestris mill). In Proceedings of the 9th International Conference on Physics and Its Applications (ICOPIA), Surakarta, Indonesia, 14 August 2018. IOP Conf. Ser. J. Phys. 2019, 1153, 012121. [CrossRef]

7. Dasenaki, M.E.; Thomaidis, N.S. Quality and authenticity control of fruit juices-A review. Molecules 2019, 24, 1014. [CrossRef]

8. Vanoli, M.; Buccheri, M. Overview of the methods for assessing harvest maturity. Stewart Postharvest Rev. 2012, 8, 1-11. [CrossRef]

9. Giuffrè, A.M. Bergamot (Citrus bergamia, Risso): The effects of cultivar and harvest date on functional properties of juice and cloudy juice. Antioxidants 2019, 8, 221. [CrossRef]

10. Hegazi, N.M.; El-Shamy, S.; Fahmy, H.; Farag, M.A. Pomegranate juice as a super-food: A comprehensive review of its extraction, analysis, and quality assessment approaches. J. Food Compos. Anal. 2021, 97, 10377-10388. [CrossRef]

11. Serra, S.; Anthony, B.; Masia, A.; Giovannini, D.; Musacchi, S. Determination of biochemical composition in peach (Prunus persica L. Batsch) accessions characterized by different flesh color and textural typologies. Foods 2020, 9, 1452. [CrossRef] [PubMed]

12. Jha, S.N.; Jaiswal, P.; Grewal, M.K.; Gupta, M.; Bhardwaj, R. Detection of adulterants and contaminants in liquid foods-A review. Crit. Rev. Food Sci. Nutr. 2016, 56, 1662-1684. [CrossRef] [PubMed]

13. Moncayo, S.; Manzoor, S.; Rosales, J.; Anzano, J.; Caceres, J. Qualitative and quantitative analysis of milk for the detection of adulteration by Laser Induced Breakdown Spectroscopy. Food Chem. 2017, 232, 322-328. [CrossRef] [PubMed]

14. Li, B.; Lecourt, J.; Bishop, G. Advances in non-destructive early assessment of fruit ripeness towards defining optimal time of harvest and yield prediction-A review. Plants 2018, 7, 3. [CrossRef]

15. Malvano, F.; Pilloton, R.; Albanese, D. Label-free impedimetric biosensors for the control of food safety-A review. Int. J. Environ. Anal. Chem. 2020, 100, 468-491. [CrossRef]

16. Euring, F.; Russ, W.; Wilke, W.; Grupa, U. Development of an impedance measurement system for the detection of decay of apples. Procedia Food Sci. 2011, 1, 1188-1194. [CrossRef]

17. Chowdhury, A.; Bera, T.K.; Ghoshal, D.; Chakraborty, B. Studying the electrical impedance variations in banana ripening using electrical impedance spectroscopy (EIS). In Proceedings of the 3rd Intelligent Conference Computing in Communication and Control (C3IT), Hoogly, India, 7-8 February 2015; pp. 1-4. [CrossRef]

18. Fernández, P.; Gabaldón, J.A.; Periago, M.J. Detection and quantification of Alicyclobacillus acidoterrestris by electrical impedance in apple juice. Food Microbiol. 2017, 68, 34-40. [CrossRef] 
19. Isa, M.M.; Ibrahim, N.; Shamsudin, R.; Marhaban, M.H. Sugar content in watermelon juice based on dielectric properties at 10.45 GHz. In Proceedings of the IEEE Student Conference on Research and Development, Serdang, Malaysia, 16-18 November 2009; pp. 529-532. [CrossRef]

20. Assawarachan, R. Estimation model for electrical conductivity of red grape juice. Int. J. Agric. Biol. Eng. 2010, 3, 52-57. [CrossRef]

21. Żywica, R.; Banach, J.K. Simple linear correlation between concentration and electrical properties of apple juice. J. Food Eng. 2015, 158, 8-12. [CrossRef]

22. Żywica, R.; Banach, J.K. Mathematical correlations between selected quality attributes and electrical parameters of apple juice. J. Food Process. Preserv. 2019, 43, e14107. [CrossRef]

23. Khan, R.; Aissa, S.B.; Sherazi, T.A.; Catanante, G.; Hayat, A.; Marty, J.L. Development of an impedimetric aptasensor for label free detection of patulin in apple juice. Molecules 2019, 24, 1017. [CrossRef]

24. Ibba, P.; Falco, A.; Abera, B.D.; Cantarella, G.; Petti, L.; Lugli, P. Bio-impedance and circuit parameters: An analysis for tracking fruit ripening. Postharvest Biol. Technol. 2020, 159, 110978-110986. [CrossRef]

25. Muñoz-Huerta, R.F.; Ortiz-Melendez, A.D.J.; Guevara-Gonzalez, R.G.; Torres-Pacheco, I.; Herrera-Ruiz, G.; Contreras-Medina, L.M.; Prado-Olivarez, J.; Ocampo-Velazquez, R.V. An analysis of electrical impedance measurements applied for plant N status estimation in lettuce (Lactuca sativa). Sensors 2014, 14, 11492-11503. [CrossRef] [PubMed]

26. Nakonieczna, A.; Paszkowski, B.; Wilczek, A.; Szypłowska, A.; Skierucha, W. Electrical impedance measurements for detecting artificial chemical additives in liquid food products. Food Control 2016, 66, 116-129. [CrossRef]

27. Grossi, M.; Riccò, B. Electrical impedance spectroscopy (EIS) for biological analysis and food characterization: A review. J. Sens. Sens. Syst. 2017, 6, 303-325. [CrossRef]

28. El Khaled, D.; Castellano, N.N.; Gazquez, J.A.; García Salvador, R.M.; Manzano-Agugliaro, F. Cleaner quality control system using bioimpedance methods: A review for fruits and vegetables. J. Clean. Prod. 2017, 14, 1749-1762. [CrossRef]

29. Juansah, J.; Yulianti, W. Studies on electrical behavior of glucose using impedance spectroscopy. IOP Conf. Ser. Earth Environ. Sci. 2016, 31, 012039. [CrossRef]

30. Cole, K.S. Permeability and impermeability of cel membranes for ions. Cold Spring Harb. Symp. Quant. Biol. 1940, 8, 110-122. [CrossRef]

31. Hayden, R.I.; Moyse, C.A.; Calder, F.W.; Crawford, D.P.; Fensom, D.S. Electrical Impedance Studies on Potato and Alfalfa Tissue. J. Exp. Bot. 1969, 20, 177-200. [CrossRef]

32. Zhang, M.I.N.; Willison, J.H.M. Electrical Impedance Analysis in Plant Tissues. J. Exp. Bot. 1991, 44, 1369-1375. [CrossRef]

33. Żywica, R.; Pierzynowska-Korniak, G.; Wójcik, J. Application of food products electrical model parameters for evaluation of apple purée dilution. J. Food Eng. 2005, 67, 413-418. [CrossRef]

34. Żywica, R.; Banach, J.K.; Modzelewska-Kapituła, M. Possibilities of the quality assessment of apple juice concentrate using its equivalent electrical model. Pol. J. Commod. Sci. 2015, 4, 80-86.

35. Żywica, R.; Modzelewska-Kapituła, M.; Zadroga, I.; Tkacz, K. Influence of selected mineral components and dry matter contents on the electrical conductivity of apple juice. Pol. J. Commod. Sci. 2017, 3, 86-94. [CrossRef]

36. Żywica, R.; Banach, J.K. Sposób prognozowania zawartości ekstraktu w sokach owocowych, zwłaszcza w soku jabłkowym (A method of predicting the extract content in fruit juices, especially in apple juice). Patent PL 224364, 15 December 2016. (In Polish)

37. Czapski, J.; Tyma, P. Metody wykrywania zafałszowań przetworów owocowych (Methods of detecting adulteration of processed fruit). Przem. Spożyw. 1996, 10, 22-25. (In Polish)

38. Security of Drinking Water Supply—Guidelines for Risk and Crisis Management-Part 2: Risk Management. PN-EN 159752:2013-12, 21 December 2016.

39. IFU. Available online: https: / /ifu-fruitjuice.com/page/ListofIFUMethods (accessed on 7 June 2021).

40. Fruit and Vegetable Juices—Determination of Titrable Acidity. PN-EN 12147:2000, 11 January 2000.

41. Fruit and Vegetable Juices—Estimation of Soluble Solids Content-Refractometric Method. PN-EN 12143:2000, PN-EN 12143:2000, 11 January 2000.

42. Fruit and Vegetable Juices—Determination of the Relative Density. PN-EN 1131:1999, 23 September 1999.

43. Fruit and Vegetable Juices—Determination of the pH-Value. PN-EN 1132:1999, 23 September 1999.

44. Pierzynowska-Korniak, G.; Żywica, R.; Wójcik, J. Electric properties of apple purée and apple juices. Eur. Food Res. Technol. 2003, 216, 385-389. [CrossRef]

45. Lee, H.S.; Wrolstad, R.E. Apple Juice Composition: Sugar, nonvolatile acid, and phenolic profiles. J. Assoc. Off. Anal. Chem. 1988, 71, 789-794. [CrossRef] [PubMed]

46. Widodo, C.S.; Santosa, D.R.; Juswono, U.P. Double layer impedance analysis on the electrical impedance measurement of solution using a parallel plate. JEEST 2016, 3, 65-69. [CrossRef]

47. Beier, W. Biophysik: Eine Einführung in die physikalische Analyse biologischer Systeme; Thieme: Leipzig, Germany, 1968.

48. Nadolna, I. Wartość żywieniowa krajowych soków warzywnych i owocowych (Nutritional value of domestic vegetable and fruit juices). In Soki Warzywne i Owocowe a Zdrowie; Wydawnictwo Borgis: Warsaw, Poland, 1998. (In Polish)

49. Mabrook, M.F.; Petty, M.C. Effect of composition on the electrical conductance of milk. J. Food Eng. 2003, 60, 321-325. [CrossRef] 
50. Mabrook, M.F.; Petty, M.C. A novel technique for the detection of added water to full fat milk using single frequency admittance measurements. Sens. Actuator B 2003, 96, 215-218. [CrossRef]

51. Żywica, R.; Banach, J.K.; Kiełczewska, K. Sposób prognozowania zawartości tłuszczu w mleku surowym i śmietance (Method for Forecasting fat Content in Raw Milk and Cream). Patent PL 207656, 28 December 2006. (In Polish) 